\title{
Wsparcie społeczne u matek i ojców dzieci z zaburzeniami rozwoju
}

Celem badania zaprezentowanego w niniejszym artykule było określenie poziomu subiektywnie spostrzeganego wsparcia społecznego u matek i ojców dzieci $\mathrm{z}$ autyzmem. W badaniu uczestniczyło 74 rodziców dzieci z autyzmem (39 matek, 35 ojców), 77 rodziców dzieci z zespołem Downa (40 matek, 37 ojców) oraz 80 rodziców dzieci rozwijających się prawidłowo (40 matek, 40 ojców). Do pomiaru tej zmiennej wykorzystano kwestionariusz SSQSR autorstwa J.G. Sarasona, H.M. Levine'a, R.B. Bashama i B.R. Sarason w polskiej adaptacji Z. Zalewskiego, Z. Obłój, B. Skuzy i K. Wrześniewskiego. Wyniki wskazują na niższą satysfakcję ze wsparcia społecznego u ojców dzieci z autyzmem niż ojców dzieci o typowym rozwoju. Ponadto matki dzieci z autyzmem oraz matki dzieci z zespołem Downa znacznie wyżej oceniają satysfakcję z otrzymywanego wsparcia społecznego niż ojcowie tych dzieci. Dodatkowo matki dzieci z zespołem Downa oceniają wyżej - niż ojcowie dzieci z tym zaburzeniem - wielkość dostępnej sieci społecznego wsparcia.

Słowa klucze: autyzm, wsparcie społeczne, stres rodzicielski, zespół Downa

\section{Social support in mothers and fathers of children with developmental disorders}

The aim of the research presented in this article was to determine the level of subjectively perceived social support at mothers and fathers of children with autism. The research involved 74 parents of children with autism (39 mothers, 35 fathers), 77 parents of children with Down syndrome ( 40 mothers, 37 fathers) and 80 parents of children developing properly ( 40 mothers, 40 fathers). The results indicate lower satisfaction from social support at fathers of children with autism than at fathers of children with typical development. In addition, mothers of children with autism and mothers of children with Down syndrome rate satisfaction with the received social support significantly higher than fathers of these children. Besides, mothers of children with Down syndrome estimate the quantity of available social support network higher than fathers of children with this disorder.

Keywords: autism, social support, parental stress, Down syndrome 


\section{Wprowadzenie}

Autyzmem, określa się zbiór zaburzeń rozwoju o charakterze neurobehawioralnym. Zgodnie z systemem klasyfikacyjnym zaburzeń psychicznych zwanym DSM (Diagnostic and Statistical Manual of Mental Disorders), opracowanym przez Amerykańskie Towarzystwo Psychiatryczne w maju 2013 r., kryteria diagnostyczne autyzmu dotyczą występowania zaburzeń w zakresie społecznego komunikowania się oraz w zakresie ograniczonych wzorców zachowania, aktywności i zainteresowań. W najnowszej wersji podręcznika DSM V wprowadzono termin "autystyczne spektrum zaburzeń" (Autism spectrum disorders - ASD), podkreślając $\mathrm{w}$ ten sposób złożony charakter problemów typowych dla autyzmu. Szczególne potrzeby rozwojowe dzieci z autyzmem oraz trudności związane z ich zachowaniem stawiają przed rodzicami ogromne wyzwania.

W badaniach nad sytuacją rodziców dzieci z zaburzeniami rozwoju istotne miejsce zajmują prace dotyczące stresu rodzicielskiego (parenting stress): jego nasilenia, źródeł oraz konsekwencji.

Wyniki szeregu badań [m.in. Allen 2004; Feldman i in. 2007; Gray 2003; Hodapp i in. 2003; Yamada i in. 2007; Pisula 2009] wskazują, że opieka nad dzieckiem z zaburzeniami rozwoju stanowi dla rodzica źródło silnego stresu oraz wywiera wpływ na funkcjonowanie wszystkich członków rodziny. Zmianie ulegają plany i cele życiowe sformułowane przez rodziców. Ponadto, niepełnosprawność dziecka wpływa na funkcjonowanie społeczne, kondycję finansową, jak również psychofizyczne zdrowie pozostałych członków rodziny [por. m.in. Kucharczyk 2011; Minczakiewicz 2010; Zasępa 2010].

Opiekunowie dzieci z autyzmem doświadczają wyjątkowych i szczególnych zmartwień/trudności, nieznanych rodzicom dzieci z innym rodzajem niepełnosprawności. Ta wyjątkowość wiąże się miedzy innymi ze specyfiką zaburzeń charakterystycznych dla autyzmu oraz dużymi trudnościami z dostępem do usług przeznaczonych dla dzieci i ich samych [m.in. Bishop i in. 2007; Bradley i in. 2004; Dunn i in. 2001; Gray 2002; Pisula 2005, 2007; Yamada i in. 2007]. Z wielu badań wynika, że rodzice dzieci z autyzmem przejawiają wyższy poziom psychicznych i fizycznych obciążeń w związku z opieką nad dzieckiem niż rodzice dzieci $\mathrm{z}$ innymi niepełnosprawnościami. Wykazano na przykład, że matki dzieci z autyzmem myślą bardziej pesymistycznie o przyszłości swojego dziecka (niezależnie od wieku dziecka) niż matki dzieci z zespołem Downa [Abbeduto i in. 2004]. Stwierdzono także wyższy poziom depresji $\mathrm{w}$ grupie rodziców sprawujących opiekę nad dzieckiem z autyzmem (m.in. Baker-Ericzen i in. 2005].

Również wyniki badań prowadzonych na gruncie polskim przekonują, iż matki sprawujące opiekę nad dzieckiem pełnosprawnym doświadczają istotnie niższe- 
go stresu w porównaniu z matkami dzieci z różnymi rodzajami niepełnosprawności [m.in. Pisula 1998, 2007, 2009]. Matki dzieci z autyzmem doświadczały przy tym, w porównaniu z matkami dzieci z innymi rodzajami niepełnosprawności, znacznie większych obciążeń. Szczególnie trudna dla tej grupy okazała się duża zależność dziecka od opieki oraz nieprzewidywalność zachowania dziecka. Podobne wyniki, również w odniesieniu do ojców, uzyskała A. Banasiak [2013]. Badaczka ta porównywała poziom doświadczanego stresu u ojców dzieci z zespołem Downa i z autyzmem oraz dzieci o prawidłowym rozwoju. Ojcowie dzieci z autyzmem w porównaniu z ojcami dzieci pełnosprawnych oceniali swoje dzieci jako bardziej zależne od opieki, a ich rozwój poznawczy oraz możliwości rozwoju fizycznego jako bardziej ograniczone. Doświadczali również silniejszego stresu związanego z perspektywą konieczności ciągłej opieki nad dzieckiem i z preferowaniem opieki instytucjonalnej. Okazało się także, że ojcowie dzieci z autyzmem, w stosunku do ojców dzieci z zespołem Downa ocenili możliwości fizyczne swojego dziecka jako bardziej ograniczone.

Zaburzenie rozwoju dziecka można rozpatrywać w kategoriach krytycznego zdarzenia życiowego, które wpływa na funkcjonowanie rodziny [por. Gray 2003; Higgins i in. 2005; Malthew i in. 2008; por. też Sekułowicz 2007]. Współcześnie uwaga badaczy skupia się jednak przede wszystkim na zasobach tkwiących w rodzinie i ich znaczeniu dla adaptacji [m.in. Hodapp 2007; Luther i in. 2005; Pisula 2007; Pisula i in. 2010; Sińska, Gałkowski 2002; Zasępa 2010, Żyta 2011]. Stres związany $\mathrm{z}$ obecnością $\mathrm{w}$ rodzinie dziecka $\mathrm{z}$ autyzmem powoduje, że rodzice muszą nauczyć się radzenia sobie $\mathrm{z}$ wieloma trudnymi sytuacjami, a także wprowadzać w życiu własnym i rodziny istotne zmiany służące adaptacji [por. Ching-Rong i in. 2008]. Jednak zarówno możliwości jak i zdolności adaptacyjne poszczególnych rodzin są bardzo zróżnicowane. Wiele z tych rodzin wyjątkowo dobrze radzi sobie z wymogami, jakie nakłada na nich choroba czy zaburzenie rozwoju dziecka. Badania dowodzą [por. Dykens 2006; Hodapp i in. 2001, 2007a], że zdobyte przez rodziców doświadczenia wypływające ze sprawowania opieki nad dzieckiem z problemami w rozwoju, mogą stać się źródłem poczucia własnej wartości oraz wzrostu samooceny.

Badania nad procesem radzenia sobie ze stresem, obecnie stanowiące jeden z podstawowych nurtów badawczych nad procesami zachodzącymi w rodzinach z dziećmi z niepełnosprawnością, wnoszą ważne informacje do analizy sytuacji tych rodzin. Pozwalają one na częściowe wyjaśnienie, dlaczego pewni ludzie znacznie lepiej umieją sprostać wyzwaniom związanym z niepełnosprawnością dziecka niż inni. Wśród szeregu czynników sprzyjających radzeniu sobie istotne miejsce zajmuje wsparcie społeczne [por. Parchomiuk 2007, 2012; por. Żyta 2011].

Nawiązując do historii, warto przypomnieć, iż zainteresowanie zjawiskiem społecznego wsparcia pojawiło się w latach 70. XX w. w badaniach psychologicz- 
nych prowadzonych w ośrodkach uniwersyteckich USA, Kanady, Holandii i Anglii [za: Jaworowska-Obłój, Skuza 1986]. Choć od tego czasu minęło wiele lat, pojęcie „wsparcia społecznego" nie doczekało się jednolitej, powszechnie akceptowanej definicji. Większość badaczy definiuje wsparcie społeczne w ujęciu funkcjonalnym. Zgodnie z takim ujęciem, wsparcie to określa się jako „rodzaj interakcji społecznej, który zostaje podjęty w sytuacji problemowej lub trudnej, polega na wymianie informacji, emocji, dóbr materialnych, może być jedno lub dwustronna i ma na celu rozwiązanie problemu lub przezwyciężenie sytuacji trudnej" [Sęk 1991: 153]. Tak rozumiane wsparcie społeczne może zachodzić w diadzie, między jednostką a grupą i pomiędzy grupami.

Znaczenie wsparcia społecznego dla dobrostanu psychicznego osoby znajdującej się $w$ sytuacji stresu było przedmiotem licznych badań. Wyniki tych prac wskazują na pozytywny wpływ wsparcia społecznego w sytuacjach trudnych/ stresowych na zachowanie zdrowia fizycznego i psychicznego oraz dobrego samopoczucia [np. Feldman i in. 2007; por. Sęk, Cieślak 2004; Terelak 2008]. Stwierdza się również, że wsparcie społeczne sprzyja podwyższaniu samooceny i poczucia zaradności oraz może wpływać na rozwijanie indywidualnych strategii radzenia sobie ze stresem [Gore 1985].

Choć wiadomo już wiele na temat roli wsparcia społecznego jako istotnego predyktora adaptacji do sytuacji trudnych, problematyka ta relatywnie rzadko bywa podejmowana $\mathrm{w}$ odniesieniu do rodziców dzieci $\mathrm{z}$ autyzmem. Z nielicznych badań wynika, że satysfakcjonujące wsparcie społeczne wiąże się ze zmniejszeniem negatywnych efektów, jakie stres rodzicielski wywiera na zachowanie matki podczas interakcji z dzieckiem z autyzmem [Feldman i in. 2002]. Co ciekawe jednak, badania wskazują na dość słabe powiązanie między wsparciem społecznym a stresem rodzicielskim w tej grupie rodziców. Przykładowo, A. Banasiak [2012] wykazała, że ujemna korelacja ze wsparciem społecznym wystąpiła jedynie w zakresie stresu związanego z zależnością dziecka od opieki. Matki dzieci z autyzmem, które deklarowały zadowolenie z otrzymywanej pomocy, spostrzegały swoje dzieci jako mniej zależne, a ojcowie rzadziej myśleli o umieszczeniu dziecka w ośrodku całodobowym [Banasiak, 2014]. Nie wykluczone zatem jest, że satysfakcja czerpana ze wsparcia społecznego odgrywa znacznie większe znaczenie na przystosowanie rodziny dziecka z autyzmem, niż na poziom doświadczanego stresu rodzicielskiego [por. Parchomiuk 2007].

Poziom satysfakcji ze wsparcia jest różny u rodziców dzieci z różnymi zaburzeniami rozwoju. Jest on niższy - jak wskazują niektóre badania [Pisula, 1998] u rodziców dzieci z zaburzeniami rozwoju niż u rodziców dzieci rozwijających się typowo, a także u rodziców dzieci z autyzmem niż u rodziców dzieci z mózgowym porażeniem dziecięcym i rodziców dzieci z zespołem Downa [Brown i in., 2006]. Dotychczas jednak nie sprawdzano, jak płeć rodzica wpływa na te zależności. 


\section{Badania własne}

W niniejszym badaniu sprawdzone zostaną różnice między wsparciem otrzymywanym przez matki i ojców dzieci z autyzmem, zespołem Downa i rozwijających się prawidłowo. Grupy rodziców dzieci z zespołem Downa oraz rodziców dzieci o typowym rozwoju stanowiły grupy porównawcze dla rodziców dzieci z autyzmem. O wyborze grupy rodziców dzieci z zespołem Downa jako porównawczej dla rodziców dzieci z autyzmem zdecydowały trzy przesłanki:

- zespół Downa jest zaburzeniem znacznie lepiej poznanym, jak również znacznie szybciej diagnozowanym niż autyzm - fakty te sprzyjają adaptacji rodzica;

- rozwój emocjonalny, zdolności komunikacyjne oraz społeczne w autyzmie zdecydowanie różnią się od obrazu klinicznego zespołu Downa;

- dostępność usług specjalistycznych dla dzieci - znacznie uboższa oferta dla autyzmu.

Pomimo powyżej zakreślonych podstawowych różnic, rodziców dzieci $\mathrm{z}$ autyzmem i z zespołem Downa wiele też łączy. Warto wymienić choćby podobieństwa trudności wynikające ze sprawowania opieki nad dzieckiem z niepełnosprawnością, reakcje społeczne na niepełnosprawność dziecka czy lęk o jego przyszłość.

\section{Osoby badane}

Badaniami została objęta grupa 231 osób, w tym 74 rodziców dzieci z autyzmem (grupa „A") (39 matek i 35 ojców), 77 rodziców dzieci z zespołem Downa (grupa „D”) (40 matek i 37 ojców) oraz 80 rodziców dzieci rozwijających się prawidłowo (grupa "N") (40 matek i 40 ojców).

Średni wiek matek dzieci z autyzmem wynosił ok. 40 lat (średnia 39,54; odchylenie standardowe 7,54), a u ojców 43 lata (średnia 43,14; odchylenie standardowe 8,32). Najwięcej rodziców posiadało wykształcenie wyższe (29 osób, 39,2\%) i pochodziło z dużego środowiska miejskiego - powyżej 100 tys. mieszkańców (48 osób, 65\%). Większość rodziców dzieci z autyzmem była także aktywna zawodowo (50 osób, 68\%).

Porównanie testem nieparametrycznym Kołmogorowa-Smirnowa pod względem rozkładu charakterystyk demograficznych wykazało, iż między grupami rodziców dzieci z autyzmem i dzieci z zespołem Downa nie było różnic w zakresie poziomu wykształcenia, wieku rodzica, środowiska zamieszkania, aktywności zawodowej oraz wieku dziecka. Między grupami rodziców dzieci z autyzmem i dzieci rozwijających się typowo wystąpiła natomiast różnica w zakresie wieku 
dziecka - w grupie dzieci rozwijających się prawidłowo więcej było dzieci w wieku 12-17 lat ( $\mathrm{p}<0,025^{*}$, średnia A: 1,55, N: 1,30, odchylenie standardowe A: 0,50, odchylenie standardowe N 0,46). Rozkład zmiennych demograficznych w grupach rodziców dzieci z zespołem Downa i dzieci rozwijających się prawidłowo także był podobny. Jedynie w zakresie wieku rodzica ( $\mathrm{p}<0,001^{*}$; średnia D 2,27; średnia N 2,62; odchylenie standardowe D 0,55; odchylenie standardowe N 0,56) i wieku dziecka ( $\mathrm{p}<0,001^{*}$; średnia D 1,30; średnia N 1,66; odchylenie standardowe D 0,46; odchylenie standardowe $\mathrm{N} 0,47$ ) wystąpiły istotne różnice. W grupie rodziców dzieci z zespołem Downa więcej było osób w wieku powyżej 40 lat oraz więcej dzieci w wieku 12-17 lat.

Grupa rodziców dzieci z autyzmem dobrana została pod względem następujących kryteriów: diagnoza dziecka (diagnoza psychiatryczna, autyzm dziecięcy), wiek dziecka - od 7 do 17 lat; korzystanie dzieci z nauki w szkołach; brak współwystępowania z autyzmem innych zaburzeń (np. mózgowego porażenia dziecięcego, zespołu Downa, innych zdiagnozowanych zaburzeń).

Grupy porównywane z grupą rodziców dzieci z autyzmem zostały dobrane na zasadach zmodyfikowanego doboru losowego. Kryteria doboru tych grup to: wiek dziecka (7-17 lat), zbliżony poziom wykształcenia matek i ojców oraz miejsce zamieszkania (odpowiednio do grupy podstawowej) oraz korzystanie dzieci z nauki w szkołach.

\section{Narzędzie badawcze}

Do pomiaru wsparcia społecznego wykorzystano kwestionariusz SSQSR autorstwa J.G. Sarasona, H.M. Levine'a, R.B. Bashama i B.R. Sarason w polskiej adaptacji Z. Zalewskiego, Z. Obłój, B. Skuzy i K. Wrześniewskiego. Narzędzie służy do pomiaru spostrzeganego wsparcia społecznego i jest krótszą, składającą się z sześciu pytań, wersją kwestionariusza The Social Questionnaire. Pozwala ono na pomiar dwóch subiektywnie ocenianych przez badanych wskaźników wsparcia: wielkości dostępnej sieci społecznej, tj. liczby osób, na których pomoc badany prawdopodobnie mógłby liczyć w różnych sytuacjach życiowych, oraz przewidywanego zadowolenia ze wsparcia, jakiego osoby te mogłyby mu udzielić.

Odpowiadając na każde pytanie, badani najpierw wymieniają inicjały osób, na których pomoc mogą liczyć (maksymalnie sześć osób) i określają relację z daną osobą (np. matka, mąż). Następnie na sześciostopniowej skali przewidują, jak bardzo byliby zadowoleni ze wsparcia, którego wymienione osoby mogłyby im udzielić.

Kontakt z rodzicami dzieci z autyzmem nawiązano za pośrednictwem szkół specjalnych, głównie takich, w których działają oddziały dla dzieci z autyzmem. 
Z rodzicami dzieci z zespołem Downa kontakt nawiązywano najczęściej poprzez szkoły i stowarzyszenia. Z kolei do rodzin dzieci rozwijających się prawidłowo docierano przez szkoły. Udział rodziców w badaniu był dobrowolny i anonimowy. Wszyscy badani zostali poinformowani o celu i charakterze badań. Po wyrażeniu zgody na udział w badaniu rodzice otrzymywali zestaw kwestionariuszy do wypełnienia $\mathrm{w}$ domu. Po okresie 2-3 tygodni, autorka niniejszej pracy osobiście odbierała je od rodziców, w miejscach wyznaczonych przez rodziców (najczęściej na terenie szkoły). Dwanaście osób z różnych przyczyn odmówiło udziału w badaniach.

\section{Wyniki}

W celu porównania badanych grup rodziców (oddzielnie matek i ojców) pod względem subiektywnej oceny otrzymywanego wsparcia społecznego wykorzystano test nieparametryczny U Manna-Whitney'a. Analizie poddano dwa wskaźniki wsparcia społecznego obliczone na podstawie wyników w Skali SSQSR: wielkość dostępnej sieci społecznej; przewidywana satysfakcja ze wsparcia. Wyniki analiz przedstawiają tabele 1 i 2 .

Analiza danych zawartych $w$ tabeli 1 wskazuje na brak istotnych statystycznie (na poziomie istotności $\mathrm{p}<0,05$ ) różnic między badanymi grupami matek. Wyniki analizy przeprowadzonej w trzech grupach ojców prezentuje tabela 2.

Jak wynika z tabeli 2 , w zakresie jednego wskaźnika wsparcia społecznego ojcowie dzieci z autyzmem osiągnęli wyniki niższe niż ojcowie dzieci rozwijających się typowo. Była to satysfakcja z otrzymywanego wsparcia społecznego. Pozostałe różnice między grupami nie były istotne statystycznie.

W celu porównania wsparcia społecznego u matek i ojców z badanych grup także przeprowadzono analizy z wykorzystaniem testu U Manna-Whitney'a. Wyniki analiz przedstawia tabela 3.

Test U Manna-Whitney'a wykazal, że w jednym obszarze wyróżniony w Skali SSQSR matki dzieci z autyzmem uzyskały wyniki istotnie wyższe niż ojcowie. Różnice wystąpiły w odniesieniu do satysfakcji z otrzymywanego wsparcia społecznego.

W grupie rodziców dzieci z zespołem Downa analiza danych wskazała na istotne statystycznie różnice między matkami a ojcami w zakresie dwóch wskaźników Skali SSQSR. We wszystkich przypadkach matki uzyskały wyniki wyższe niż ojcowie. Nie stwierdzono różnic między matkami a ojcami dzieci rozwijających się prawidłowo. 


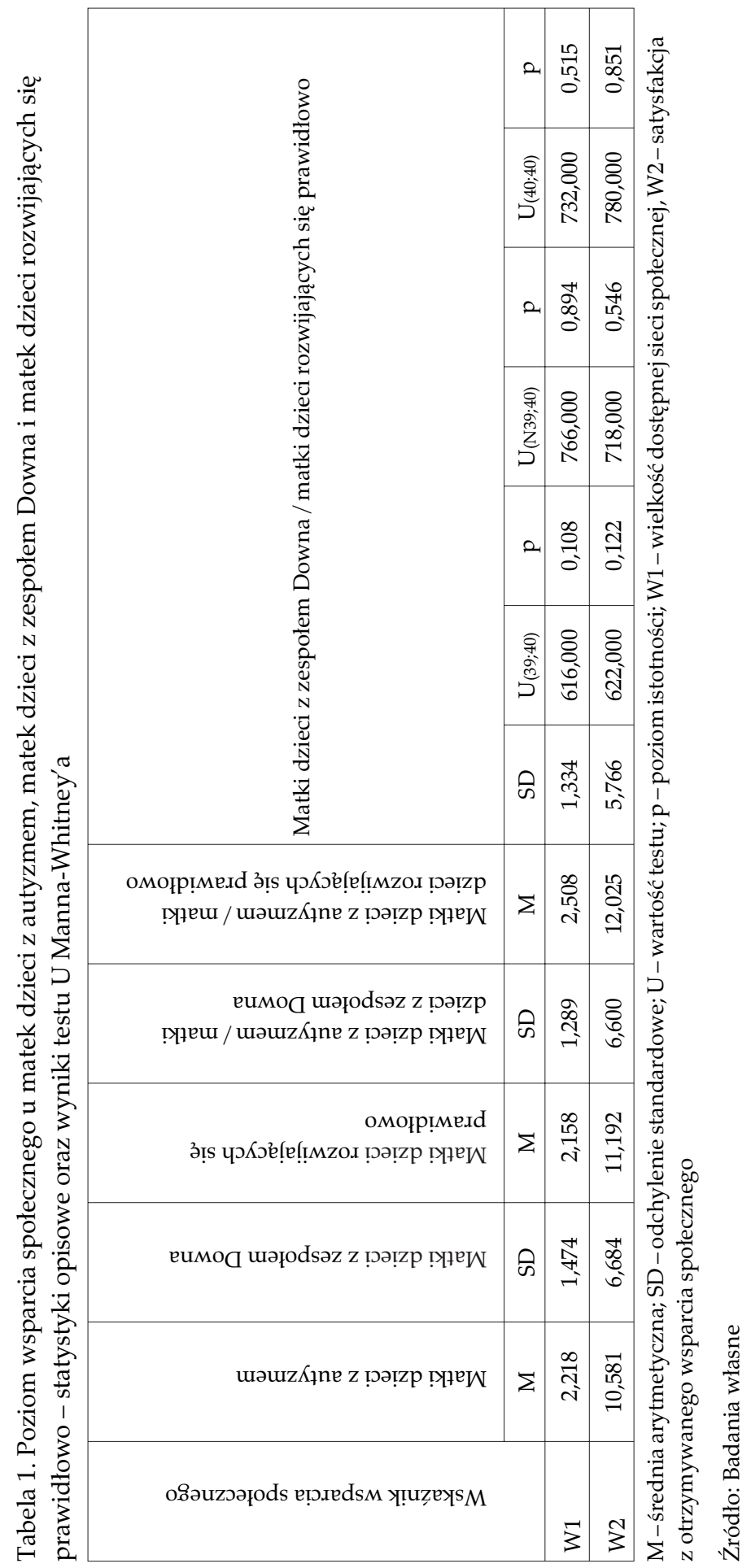




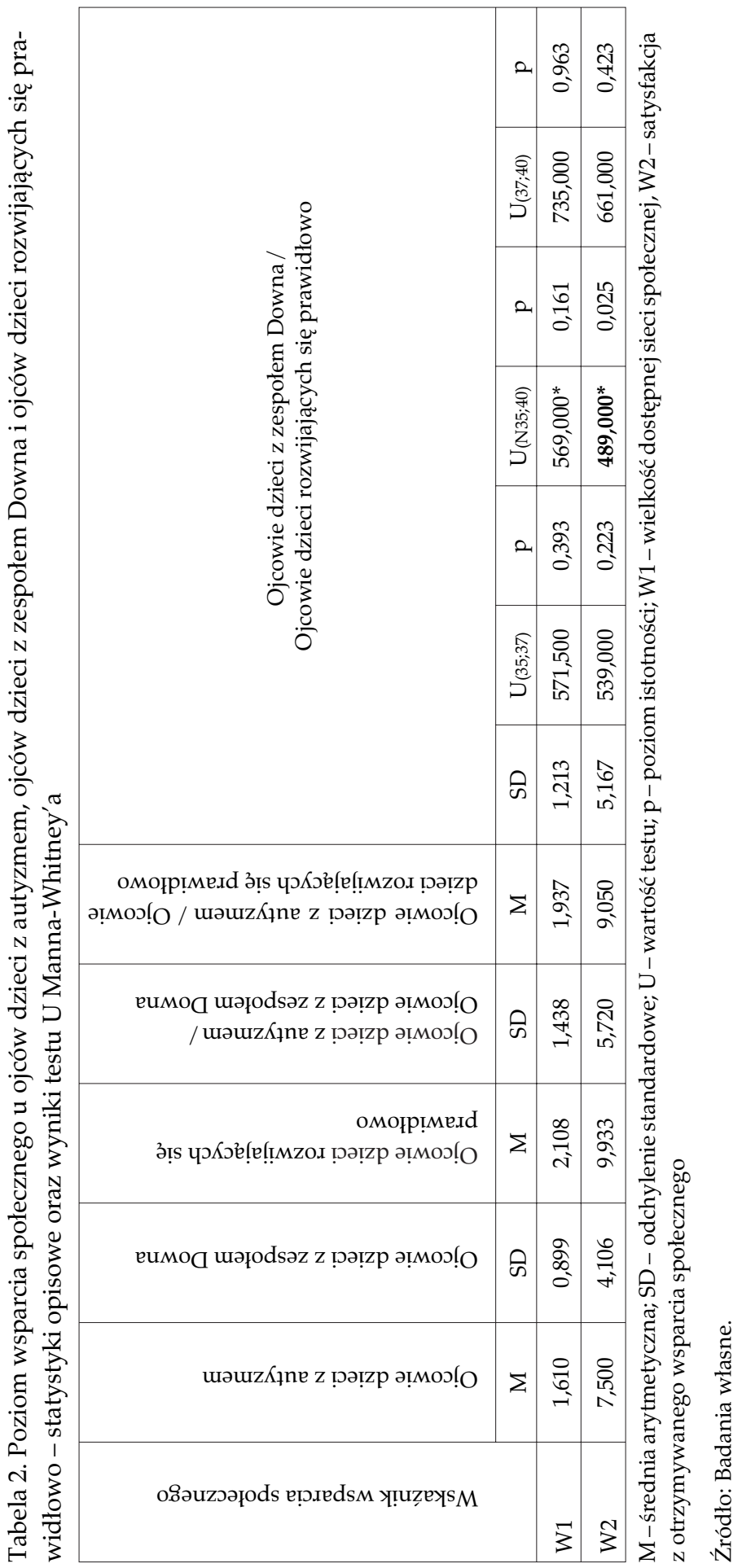


Tabela 3. Poziom wsparcia społecznego u matek i ojców dzieci z autyzmem, matek i ojców dzieci z zespołem Downa oraz matek i ojców dzieci rozwijających się prawidłowo - wyniki testu U Manna-Whitney'a

\begin{tabular}{|c|c|c|c|c|c|c|}
\hline \multirow{2}{*}{$\begin{array}{c}\text { Wskaźnik } \\
\text { wsparcia } \\
\text { społecznego }\end{array}$} & \multicolumn{2}{|c|}{$\begin{array}{c}\text { Ojcowie/matki dzieci } \\
\text { z autyzmem }\end{array}$} & \multicolumn{2}{c|}{$\begin{array}{c}\text { Ojcowie/matki dzieci roz- } \\
\text { wijających się prawidłowo }\end{array}$} & \multicolumn{2}{c|}{$\begin{array}{c}\text { Ojcowie/matki dzieci } \\
\text { z zespołem Downa }\end{array}$} \\
\cline { 2 - 7 } & $\mathrm{U}_{(\mathrm{N} 35 ; 39)}$ & $\mathrm{p}$ & $\mathrm{U}(\mathrm{N} 40 ; 40)$ & $\mathrm{p}$ & $\mathrm{U}_{(37 ; 40)}$ & $\mathrm{p}$ \\
\hline SSQSR W1 & 563,000 & 0,193 & 740,000 & 0,565 & $\mathbf{5 4 5 , 0 0 0}$ & 0,046 \\
\hline SSQSR W2 & $\mathbf{4 9 1 , 0 0 0}$ & 0,038 & 682,000 & 0,258 & $\mathbf{4 7 3 , 0 0 0}$ & 0,007 \\
\hline
\end{tabular}

W1 - wielkość dostępnej sieci społecznej, W2 - satysfakcja z otrzymywanego wsparcia społecznego, $\mathrm{U}$ - wartość testu, $\mathrm{p}$ - poziom istotności

Źródło: Badania własne.

\section{Podsumowanie}

W niniejszej pracy przedmiotem szczególnego zainteresowania uczyniono poznanie subiektywnie spostrzeganego wsparcia społecznego przez matki i ojców dzieci z autyzmem i zespołem Downa, na tle grupy rodziców dzieci rozwijających się typowo. Zastosowana w tym celu analiza wykazała niewiele istotnych różnic w ocenach wskaźników wsparcia społecznego między badanymi grupami rodziców. Jedynie między ojcami dzieci z autyzmem a ojcami dzieci neurotypowymi zaobserwowano istotne różnice. Ojcowie dzieci z autyzmem ocenili satysfakcję z otrzymywanego wsparcia społecznego znacznie niżej niż ojcowie dzieci rozwijających się prawidłowo. Uzyskany rezultat pozostaje w zgodzie z wynikami innych badań, w których to stwierdzono mniejsze zadowolenie z otrzymywanego wsparcia społecznego u rodziców dzieci z autyzmem niż rodziców dzieci z innymi zaburzeniami rozwoju oraz rodziców dzieci rozwijających się typowo [m.in. Brown i in. 2006; Sekułowicz 2007].

Warto podkreślić, że nie każde wsparcie przynosi pozytywny skutek. Ważne w tym względzie jest dopasowanie jego rodzaju, źródła i wielkości do oczekiwań osoby potrzebującej. Możliwe są zatem niekorzystne efekty oferowanego wsparcia. Badacze sugerują, że najczęściej ma to miejsce, gdy przyczynia się ono do obniżenia przekonania o własnej skuteczności i do poczucia braku kompetencji - co w konsekwencji powoduje, że wsparcie nie jest spostrzegane jako pomocne [Deelstra i in. 2003; Sęk 2000]. J.T. Deelstra i in. [2003] są zdania, że w szczególności negatywny efekt przynosi wsparcie, które jest narzucone biorcy, zatem wbrew jego woli i oczekiwania takiego wsparcia. Warto o tym pamiętać i traktować jako ważną przesłankę w praktyce pomocowej.

Na komentarz zasługuje wynik wskazujący na brak istotnych różnic w grupach badanych matek. Na podstawie wcześniejszych eksploracji [Benson 2006; 
Błaszczyk 2008; Dunn i in. 2001; Montes i in. 2007; Weiss 2002; Tobing i in. 2006], wskazujące na doświadczane przez matki dzieci z autyzmem poczucie osamotnienia, odrzucenia oraz izolację społeczną, jak również poczucie niepewności i niejasności gdzie i jakiej pomocy szukać, można było oczekiwać, że niżej będą oceniać poziom otrzymywanego wsparcia, jak również dysponować mniejszą liczbą osób tworzących sieć. Wyniki badań pochodzące z lat 90 . ubiegłego stulecia wskazywały na różny poziom satysfakcji ze wsparcia ze względu na rodzaj niepełnosprawności dziecka, przy czym u matek dzieci z autyzmem poziom ten był najniższy. Być może na uzyskany wynik (brak różnic między badanymi matkami) wpływ ma coraz to lepsza i bardziej dostępna sieć usług specjalistycznych dla dzieci z zaburzeniami rozwoju i ich rodzin.

Wiele zmieniło się w systemie edukacji, w której ustawowo wprowadzono pomoc psychologiczno-pedagogiczną dla dziecka/ucznia jak i jego rodziny. Rodzic współuczestnicząc $\mathrm{w}$ tworzeniu IPET-u dla swojego dziecka, bezwątpienia doświadcza poczucia sprawczości w zakresie jego "szkolnego wzrastania". Współczesne placówki oferują oprócz edukacji szeroko rozumianą pomoc terapeutyczną, prowadzoną przez wyspecjalizowaną kadrę nauczycieli. Zakres oferowanej pomocy do niedawna dostępny tylko na rynku usług prywatnych, obecnie często realizowany jest także $\mathrm{w}$ placówkach ogólnodostępnych, co wyrównuje szanse dzieciom rodzin mniej zamożnych. Być może nie bez znaczenia dla uzyskanego rezultatu pozostaje także rozwój trzeciego sektora, czyli organizacji pozarządowych $w$ pozyskiwaniu środków unijnych. Niewiele matek pozostaje niezrzeszonych poza stowarzyszeniami czy fundacjami, oferującymi szeroko rozumiane wsparcie. Świadome uczestnictwo zarówno w podejmowaniu decyzji, jak i w procesach wpływających na zmianę sytuacji danej osoby sprzyja dobrostanowi psychicznemu jednostki.

Wspomniane hipotezy wyjaśniające wymagają jednak pogłębionych analiz empirycznych.

Potwierdzone zostały także wyniki wcześniejszych badań wskazujące na różnice $\mathrm{w}$ ocenie otrzymywanego wsparcia społecznego między matkami a ojcami. Wykazano bowiem, że matki dzieci z zaburzeniami rozwoju (autyzm, zespół Downa) znacznie wyżej oceniły satysfakcję z otrzymywanego wsparcia społecznego niż ojcowie tych dzieci. Dodatkowo matki dzieci z zespołem Downa uzyskały wyższe wyniki w zakresie wielkości dostępnej sieci społecznej niż ojcowie z tej grupy. Uzyskane wyniki są zbieżne z tymi, jakie określono w innych badaniach $\mathrm{z}$ udziałem rodziców dzieci z zaburzeniami rozwoju. Podobnie jak $w$ niniejszych analizach wykazano tam różnice między matkami a ojcami w zakresie: potrzeby wsparcia, mobilizacji, percepcji oraz wykorzystywania. Matki dzieci z autyzmem częściej poszukiwały wsparcia niż ojcowie, jak również czerpały z niego większą satysfakcję [Malthew i in. 2008; Sińska, Gałkowski 2002]. Zdecydowanie wyżej 
oceniały pomoc uzyskaną od innych, w porównaniu z ojcami, dla których nie była ona szczególnie istotna [Krauss 1993]. Podobne wyniki uzyskała także A. Banasiak [2013a]. Przynależność do organizacji społecznej (stowarzyszeń ludzi doświadczających podobne trudności) u ojców wiązała się z wyższym poziomem stresu $\mathrm{w}$ porównaniu z ojcami niezrzeszonymi. Z kolei matki zrzeszone w organizacjach społecznych doświadczały niższego poziomu stresu w porównaniu do matek niezrzeszonych. Różnice te wynikają z nieco innej emocjonalności i ekspresyjności kobiet i mężczyzn. Z założenia kobiety jako bardziej otwarte, empatyczne i skłonne do ekspresji częściej znajdują zrozumienie i wsparcie u innych. Mężczyźni natomiast są mniej otwarci, traktujący relacje z innymi bardziej formalnie.

Wspomniane różnice powinny być traktowane jako ważne wytyczne w opracowywaniu oferty pomocy. Inna jest również rola ojca w wychowaniu dziecka, inne są oczekiwania rodziny wobec niego. $W$ rezultacie oferta wsparcia ojca musi się różnić jakościowo od wsparcia adresowanego do matki.

W pogłębieniu problematyki warto byłoby zbadać związek pomiędzy wsparciem społecznym a postawami rodzicielskimi. $Z$ wielu badań wynika [m.in. Domarecka-Malinowska 1997; Kruk-Lasocka 1990], że doświadczane przez rodziców dzieci niepełnosprawnych poczucie bezsilności i bezradności, będące konsekwencją sprawowania stałej opieki, braku widocznych postępów w rozwoju dziecka oraz problemów z właściwą oceną jego możliwości, implikuje u nich postawę albo nadmiernie ochraniająca/nadopiekuńczą, albo niechęci i odrzucenia dziecka. Wiadomo także, że postawy, jakie prezentują rodzice względem dziecka, kształtują się stopniowo, ulegają swoistym zmianom, zgodnie z procesem przystosowania. Nasuwa się w związku z tym pytanie, jak rodzice z określoną postawą rodzicielską oceniają otrzymywane wsparcie społeczne.

W sytuacjach trudnych/stresowych niezwykle ważna jest obecność kogoś bliskiego. Więź z innymi chroni przed poczuciem alienacji i już przez to wzmacnia odporność psychiczną [por. Kawczyńska-Butrym 1996]. Wsparcie społeczne to zasób wyjątkowo istotny w kontekście adaptacji rodziców dzieci z zaburzeniami rozwoju. Pozostaje on $\mathrm{w}$ powiązaniu $\mathrm{z}$ poziomem doświadczanego stresu rodzicielskiego. W kontekście badań [Hastings, Johnson 2001] potwierdzających związek między wysokim poziomem stresu a spostrzeganiem dziecka i jego możliwości oraz pesymizmem rodzica a mniejszą gotowością pomocy dziecku, należy zwrócić szczególną uwagę na adekwatność/trafność oferowanego wsparcia społecznego.

\section{Bibliografia}

Abbeduto L., Seltzer M.M., Shattuck P., Krauss M. W., Orsmond G., Murphy M.M. (2004), Psychological well-being and coping in mothers of youths with autism, Down syndrome, or fragile X syndrome, "American Journal of Mental Retardation”, vol. 109, s. 237-254. 
Allen C. (2004), The relationship of stress, coping and other factors in parents of children with autism, „Dissertation Abstracts International: Section B: The Sciences and Engineering”, vol. 64, s. 6319.

Baker-Ericzen M.J., Brookman-Frazee L., Stahmer L. (2005), Stress levels and adaptability in parents of toddiers with and without autism spectrum disorders, „Research Practice for Persons with Severe Disabilities", vol. 30, s. 194-204.

Banasiak A. (2012). Wsparcie społeczne a poziom doświadczanego stresu rodzicielskiego u matek dzieci z zaburzeniami rozwoju [w:] Praca socjalna aktywnym instrumentem polityki spotecznejod wolontariatu do zatrudnienia, M. Mirowska (red.), Wydawnictwo AJD w Częstochowie, Częstochowa, s. 149-161.

Banasiak A. (2013), Stres rodzicielski ojców dzieci z autyzmem, w: Świat rodziny. Perspektywa interdyscyplinarna wobec wyzwań i zagrożen, J. Garbula, A. Zakrzewska, W. Sawczak (red.), Wydawnictwo Adam Marszałek, Toruń, s. 78-94.

Banasiak A. (2013a), Znaczenie grup wsparcia w adaptacji rodziców dzieci z autyzmem, „Pedagogika Rodziny", nr 3(4), s. 129 - 141.

Banasiak A. (2014), Wsparcie społeczne a stres rodzicielski u ojców dzieci z autyzmem, „Pedagogika Rodziny", nr 4(4), s. 177-189.

Benson P.R. (2006), The in past of child symptom severity on depressed mood among parents of children with ASD: The mediating role of stress proliferation, "Journal of Autism and Developmental Disorders", vol. 36, s. 685-695.

Bishop S.L., Richler J., Cain A.C., Lord C. (2007), Predictors of perceived negative impact in mothers of children with autism spectrum disorder, "American Journal on Mental Retardation”, vol. 112, s. 450-461.

Błaszczyk S. (2008), Funkcjonowanie psychospołeczne rodziców i rodzeństwa dziecka autystycznego, „Problemy Opiekuńczo-Wychowawcze”, nr 3, s. 40-45.

Bradley E.A., Summers J.A., Wood H.L., Bryson S.E. (2004), Comparing rates of psychiatric and behavior disorders in adolescents and young adutis with severe intellectual disability with and without autism, "Journal of Autism and Developmental Disorders", vol. 34, s. 151-161.

Brown R.I., MaCadam-Crisp J., Wang M., Iarocci G. (2006), Family quality of life when there is a child with developmental disability, "Journal of Policy and Practice in Intellectual Disability", vol. 3, s. 238-245.

Ching-Rong Lin, Yun-Fang Tsai, Hsuch-Ling Chang (2008), Coping mechanisms of parents of children recently diagnosed with autism in Taiwan: a qualitative study, "Journal of Clinical Nursing", vol. 17, s. 2733-2740.

Deelstra J.T., Peeters M.C.W., Schaufeli W.B., Stroebe W., Zijlstra F.R.H. (2003), Receiving instrumental support at work: When help is not welcome, "Journal of Applied Psychology", vol. 88, s. 324-331.

Domarecka-Malinowska E. (1997), Rodzina dziecka niepetnosprawnego [w:] Wybrane problemy z pedagogiki specjalnej, E. Tomasik (red.), WSPS, Warszawa, s. 71-75.

Dykens E.M. (2006). Toward a positive psychology of mental retardation, „American Journal of Orthopsychiatry", vol. 76, s. 185-193.

Dunn M.E., Burbine T., Bowers C.A., Dunn S.T. (2001), Moderators of stress in parents of children with autism, "Community Mental Health Journal”, vol. 37, s. 39-51.

Feldman, M. A., Varghese, J., Ramsay, J., Rajska, D. (2002). Relationships between social support, stress and mother-child interactions in mothers with intellectual disabilities, "Journal of Applied Research in Intellectual Disabilities", vol. 15, s. 314-323. 
Feldman M., McDonald L., Serbin L., Stack D., Secco M.L., Yu C.T. (2007), Predictors of depressive symptoms in primary caregivers of young children with or at risk for developmental delay, "Journal of Intellectual Disability Research", vol. 51, s. 606-619.

Gore S. (1985), Social support and styles of coping with stress, w: Social support and health, S.L. Cohen, S. Syme, F.L. Orlando (red.), Academic Press, s. 263-279.

Gray D.E. (2002), Ten years on: a longitudinal study of families of children with autism, "Journal of Intellectual \& Developmental Disability", vol. 27, s. 215-222.

Gray D.E. (2003), Gender and coping: the parents of children with high functioning autism, „Social Science and Medicine", vol. 56, s. 631-642.

Hastings R.P., Johnson E. (2001), Stress in U. K. families conducting intensive home based behavioral intervention for their young child with autism, ,Journal of Autism and Developmental Disorders", vol. 31, s. 327-336.

Higgins D.J., Bailey S.R., Pearce J.C. (2005), Factors associated with functioning style and coping strategies of families with a child with an autism spectrum disorder, „Autism. The International Journal of Research and Practice", vol. 9, s. 125-137.

Hodapp R.M., Ly T.M., Fidler D.J., Ricci L.A. (2001), Less stress, more rewaring: parenting children with Down syndrome, „Parenting: Science and Practice”, vol. 1, s. 317-337.

Hodapp R.M., Ricci L.A., Fidler D.J. (2003), The effects of the child with Down syndrome on maternal stress, „British Journal of Developmental Psychology”, vol. 21, s. 137-151.

Hodapp R.M. (2007), Families of persons with Down syndrome: New perspective, findings, and research and sernice needs, "Mental Retardation and Developmental Disabilities Research Reviews", vol. 13, s. 279-287.

Hodapp R.M., Urbano R.C. (2007a), Adult siblings of individuals with Down syndrome versus with autism: Finding from large scale US survey, ,Journal of Intellectual Disability Research", vol. 51, no. 12, s. 1018-1029.

Jaworska-Obój Z., Skuza B. (1986), Pojęcie wsparcia społecznego i jego funkcje w badaniach naukowych, "Przegląd Psychologiczny”, nr 3, s. 733-746.

Kawczyńska-Butrym Z. (1996), Niepetnosprawność - specyfika pomocy społecznej, Wydawnictwo BPS Interart, Warszawa.

Krauss M.V. (1993), Child-related and parenting stress: Similarities and differences between mothers and fathers of children with disabilities, "American Journal on Mental Retardation", vol. 97, s. 393-404.

Kruk-Lasocka J. (1990), Traumatyzujący wpływ dziecka upośledzonego umysłowo na rodzinę, „Roczniki Pedagogiki Specjalnej”, nr 1, s. 91-105.

Kucharczyk J. (2011), Osobowość a inteligencja emocjonalna matek matych dzieci objętych postępowaniem terapeutyczno-rehabilitacyjnym, „Niepełnosprawność. Rodzina z dzieckiem niepełnosprawnym", nr 6, s. 63-81

Luther H.D., Canham L.D., Cureton Y.V. (2005), Coping and social support for parents of children with autism, "Journal of School Nursing", vol. 21, s. 40-47.

Malthew J., Kluge S. (2008), Family functioning and coping behaviors in parents of children with autism, "Child \$ Family Studiem", vol. 18, s. 83-92.

Minczakiewicz E. (2010), Sytuacja rodzin z dzieckiem z zespołem Downa na tle sytuacji wspótczesnych polskich rodzin statystycznych [w:] Rodzina osób z niepetnosprawnościa intelektualna wobec wyzwań wspótczesności, Z. Żyta (red.), Wydawnictwo Edukacyjne Akapit, Toruń, s. $41-55$. 
Montes G., Halterman J.S. (2007), Psychological functioning and coping among mothers of children with autism: A population based study, „Pediatrics”, vol. 119, s. 1040-1046.

Parchomiuk M. (2007), Rodzice dzieci z mózgowym porażeniem dziecięcym, Wydawnictwo Uniwersytetu Marii Curie-Skłodowskiej, Lublin.

Parchomiuk M. (2012), Zasoby osobiste matek dzieci niepetnosprawnych, „Człowiek, Niepełnosprawność, Społeczeństwo", nr 1(15), s. 43-66.

Pisula E. (1998), Psychologiczne problemy rodziców dzieci z zaburzeniami rozwoju, Wydawnictwo UW, Warszawa.

Pisula E. (2005), Problemy rodziców dorastających i dorostych osób z autyzmem [w:] Edukacja i wspomaganie rozwoju osoby z autyzmem od dzieciństwa do dorosłości, I. Matczak, A. Pala (red.), Wydawca Organizatorzy V Forum, Częstochowa, s. 91-106.

Pisula E. (2007), Rodzice i rodzeństwo dzieci z zaburzeniami w rozwoju, Wydawnictwo Uniwersytetu Warszawskiego, Warszawa.

Pisula E. (2009), Samotność wśród najbliższych. Interakcje dzieci z autyzmem z rodzicami, „Czasopismo Psychologiczne", nr 15, s. 295-304.

Pisula E., Kossakowski Z. (2010), Sense of coherence and coping with stress among mothers and fathers of children with autism, "Autism Dev Disord”, 10.10007, 10803-010-1001-3.

Sekułowicz M. (2007), Rodzina wobec niepetnosprawności dziecka - problemy adaptacji i funkcjonowania [w:] Interdyscyplinarność procesu wczesnej interwencji wobec dziecka i jego rodziny, G. Kwaśniewska (red.), Wydawnictwo UMCS, Lublin.

Sęk H. (1991), Life stress in various domains and perceived effectiveness of social support, „Polish Psychological Bulletion", vol. 22, s. 151-161.

Sęk H. (2000), Wypalanie zawodowe. Przyczyny, mechanizmy, zapobieganie, Wydawnictwo Naukowe PWN, Warszawa.

Sęk H., Cieślak R. (2004), Wsparcie społeczne - sposoby definiowania, rodzaje i źródta wsparcia, wybrane koncepcje teoretyczne [w:] Wsparcie społeczne, stres i zdrowie, H. Sęk, R. Cieślak (red.), Wydawnictwo Naukowe PWN, Warszawa, s. 11-28.

Sińska J., Gałkowski T. (2002). Radzenie sobie ze stresem i plany życiowe rodzin wychowujacych dzieci z autyzmem, „Dziecko Autystyczne”, nr 10, s. 5-28.

Terelak J. F. (2008), Człowiek i stres, Oficyna Wydawnicza „Branta”, Bydgoszcz-Warszawa.

Tobing L.E., Glenwick D.S. (2006), Predictors and moderators of psychological distress in mothers of children with pervasive developmental disorders, "Journal of Family Social Work", vol. 10, s. $1-22$.

Weiss M.J. (2002), Hardiness and social support as predictors of stress in mothers of typical children, children with autism, and children with mental retardation, "Autism”, vol. 6, s. 115-130.

Yamada A., Suzuki M., Kato M., Tanaka S., Shindo T., Taketani K., Akechi T., Furukawa T. (2007), Emotional distress and its correlates among parents of children with pervasive developmental disorders, „Psychiatry \& Clinical Neurosciences”, vol. 61, s. 651-657.

Zasępa E. (2010), Poczucie koherencji rodziców dzieci z zaburzeniami rozwoju, w:, Rodzina osób z niepetnosprawnością intelektualna wobec wyzwań wspótczesności, Z. Żyta (red.), Wydawnictwo Edukacyjne Akapit, Toruń, s. 71-84.

Żyta A. (2011), Życie z zespołem Downa, Oficyna Wydawnicza „Impuls”, Kraków. 